\title{
Thin-ice dynamics and ice production in the Storfjorden polynya for winter seasons 2002/2003-2013/2014 using MODIS thermal infrared imagery
}

\author{
A. Preußer, S. Willmes, G. Heinemann, and S. Paul \\ Dept. of Environmental Meteorology, Faculty of Regional and Environmental Sciences, \\ University of Trier, Trier, Germany \\ Correspondence to: A. Preußer (preusser@uni-trier.de) \\ Received: 10 October 2014 - Published in The Cryosphere Discuss.: 13 November 2014 \\ Revised: 13 April 2015 - Accepted: 16 April 2015 - Published: 21 May 2015
}

\begin{abstract}
Spatial and temporal characteristics of the Storfjorden polynya, which forms regularly in the proximity of the islands Spitsbergen, Barentsøya and Edgeøya in the Svalbard archipelago under the influence of strong northeasterly winds, have been investigated for the period of 2002/2003 to $2013 / 2014$ using thermal infrared satellite imagery. Thinice thicknesses were calculated from MODIS ice-surface temperatures combined with ECMWF ERA-Interim atmospheric reanalysis data in an energy-balance model. Associated quantities like polynya area and total ice production were derived and compared to previous remote sensing and modeling studies. A basic coverage-correction scheme was applied to account for cloud gaps in the daily composites. On average, both polynya area and ice production are thereby increased by about $30 \%$. The sea ice in the Storfjorden area experiences a late fall freeze-up in several years over the 12winter period, which becomes most apparent through an increasing frequency of large thin-ice areas until the end of December. In the course of an average winter season, ice thicknesses below $10 \mathrm{~cm}$ are dominating within the Storfjorden basin. During the regarded period, the mean polynya area is $4555.7 \pm 1542.9 \mathrm{~km}^{2}$. Maximum daily ice production rates can reach as high as $26 \mathrm{~cm} \mathrm{~d}^{-1}$, while the average ice production is estimated at $28.3 \pm 8.5 \mathrm{~km}^{3}$ per winter and therefore lower than in previous studies. Despite this comparatively short record of 12 winter seasons, a significant positive trend of $20.2 \mathrm{~km}^{3}$ per decade could be detected, which originates primarily from a delayed freeze-up in November and December in recent winter seasons. This contrasts earlier reports of a slightly negative trend in accumulated ice production prior to 2002. Although featuring more pronounced in-
\end{abstract}

terannual variations between 2004/2005 and 2011/2012, our estimates underline the importance of this relatively small coastal polynya system considering its contribution to the cold halocline layer through salt release during ice-formation processes. In addition, calculated quasi-daily thin-ice thickness charts represent a valuable data set for atmosphere and ocean modeling applications.

\section{Introduction}

Recurrent polynyas are considered to play an important role for sea-ice production and ocean circulation (Barber and Massom, 2007). The knowledge of ice production (IP) in the Arctic is of vital interest for the understanding of the Arctic climate system and the verification of climate and ocean models. Divergent ice motions due to wind are the main cause for the opening of near-coastal polynyas (Smith et al., 1990). During winter, these areas of open water or thin ice, exposed to the cold atmosphere, are characterized by strong ice production and brine release and modify the atmospheric boundary layer (Ebner et al., 2011; Bauer et al., 2013). The timing, duration and size of a polynya can often have large interannual variations because of the general interannual variability of atmosphere-ice-ocean interaction processes (Morales-Maqueda et al., 2004). A precise derivation of the thin-ice thickness (TIT) distribution, the areal extent of a polynya (here defined as open water and thin ice below $0.2 \mathrm{~m}$ ) and the amount of local sea-ice production is therefore an important step towards a comprehensive understanding of 


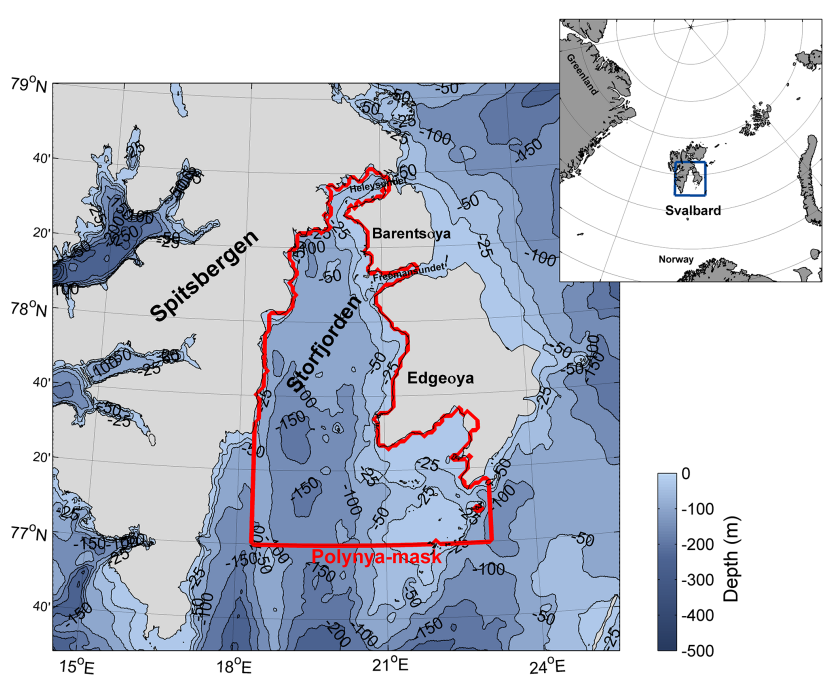

Figure 1. Map of the Svalbard archipelago in western Barents Sea. The study region is located in Storfjorden, which is surrounded by the main island Spitsbergen in the west and Barentsøya/Edgeøya in the east. The applied polynya mask is marked in red, enclosing the Storfjorden basin north of the sill at $77^{\circ} \mathrm{N}$. Bathymetric data by Jakobsson et al. (2012) (IBCAO v3.0).

physical processes in the Arctic shelf regions and the Arctic sea-ice cover in general. Ice production in thin-ice regions can either be estimated by the use of remote sensing methods (Willmes et al., 2010) or by using model approaches (Ebner et al., 2011; Krumpen et al., 2011; Bauer et al., 2013). The use of thermal infrared and microwave remote sensing data offers the opportunity for daily monitoring of thin-ice thicknesses and their distribution on large spatial scales (Yu and Rothrock, 1996; Willmes et al., 2010; Adams et al., 2013).

Storfjorden (see Fig. 1), situated in the southeastern part of the Svalbard archipelago between the main island of Spitsbergen in the west and Barentsøya/Edgeøya in the east, is a region of high coastal polynya activity during winter, as reported by a number of earlier studies (e.g., Haarpaintner et al., 2001; Skogseth et al., 2004). Two shallow straits, Heleysundet and Freemansundet, connect the northern part of Storfjorden with the Barents Sea and show tidally induced currents as well as exchange processes between water masses inside the fjord and the Barents Sea (Skogseth et al., 2013).

Persistent and strong northerly to northeasterly winds are the main cause for larger polynya openings inside Storfjorden. These opening events may result in large volumes of brine-enriched shelf water, which can be significant regarding the total amount of bottom water in the Arctic Ocean by supplying between 5 and $20 \%$ of all the newly formed dense water (Skogseth et al., 2004; Hendricks et al., 2011). Besides thermodynamically induced ice growth in Storfjorden during wintertime, the dynamical part due to rafting and deformation processes may play a substantial role in the overall ice-thickness distribution, as southerly (onshore) winds can potentially advect sea ice from the Barents Sea into the fjord (Hendricks et al., 2011). An estimation of thermodynamic IP within the open water and thin-ice area (i.e., Storfjorden polynya) has been conducted in previous studies using mainly microwave remote sensing (both passive and active systems) in combination with different model approaches. Therein, values are ranging between 20 and $35-45 \mathrm{~km}^{3}$ for single winter seasons (November-May) between 1997/1998 and 2000/2001 (Haarpaintner et al., 2001; Skogseth et al., $2004,2005)$ and $47 \mathrm{~km}^{3}$ when averaged over the winter seasons (October/November-June/July) from 2002/2003 to 2011/2012 (Jardon et al., 2014). Iwamoto et al. (2014) state that the Storfjorden polynya contributes with around $4 \%$ to the average total ice volume produced in Arctic polynyas between 2002/2003 and 2010/2011 (September to May).

While these estimates make the Storfjorden area appear to be of minor importance regarding overall ice production in Arctic polynyas, we chose this region due to several distinct requirements. These included the availability of a number of related polynya studies in order to set our estimates into a proper context as well as the comparatively small spatial extent of the Storfjorden polynya to profit from the enhanced resolution imagery.

Based on daily empirically derived ice-thickness distributions in thin-ice areas at a comparatively high spatial resolution, we perform a broad investigation on the associated quantities polynya area (POLA) and ice production for the period between 2002/2003 and 2013/2014 using highresolution Moderate Resolution Imaging Spectroradiometer (MODIS) thermal infrared data. The presented results will develop a more comprehensive understanding of the polynya dynamics in Storfjorden as well as associated processes over both annual and interannual timescales (in the course of this paper, the term "annual" refers to one winter season from November to March). Furthermore, results will contribute to pan-arctic studies of polynya dynamics.

\section{Data and methods}

\subsection{MODIS ice-surface temperatures}

Thin-ice thickness are computed using the MOD/MYD29 sea-ice product (Hall et al., 2004; Riggs et al., 2006) derived from MODIS satellite data. We used data from both MODIS instruments on board the Terra and Aqua polar-orbiting satellite platforms. They are available from the National Snow and Ice Data Center (NSIDC) located in Boulder, USA (ftp: //n5eil01u.ecs.nsidc.org/SAN/). The product contains swath data of ice-surface temperatures (ISTs). Swath-based ISTs have a spatial resolution of $1 \mathrm{~km} \times 1 \mathrm{~km}$ at nadir. The accuracy of the MOD/MYD29 ISTs is given with 1-3 K (Hall et al., 2004).

For our analysis, swaths covering the Storfjorden area were extracted using metadata information for each MODIS 
Table 1. Total number of individual MODIS swaths, which were incorporated into the thin-ice thickness (TIT) calculations. Numbers are given for each winter season from November to March.

\begin{tabular}{lc}
\hline Winter season & Number of MODIS swaths \\
\hline $2002-2003$ & 4054 \\
$2003-2004$ & 4023 \\
$2004-2005$ & 4062 \\
$2005-2006$ & 4073 \\
$2006-2007$ & 3990 \\
$2007-2008$ & 4069 \\
$2008-2009$ & 4135 \\
$2009-2010$ & 4142 \\
$2010-2011$ & 4205 \\
$2011-2012$ & 4129 \\
$2012-2013$ & 4137 \\
$2013-2014$ & 4244 \\
\hline Sum & 49263 \\
\hline
\end{tabular}

swath, resulting in 27 individual swaths per day on average for later composite generation. These composites solely consist of nighttime scenes to exclude the influence of incident shortwave radiation (Yu and Lindsay, 2003; Adams et al., 2013; cf. Sect. 2.3 and 2.3.1). The total number of incorporated MODIS swaths is illustrated in Table 1. As MODIS swath data presumably suffer from inherent panoramic distortion effects, all IST swaths were mapped onto a $2 \mathrm{~km} \times$ $2 \mathrm{~km}\left(0.018^{\circ}\right)$ equirectangular grid covering the southern part of Svalbard $\left(75-80^{\circ} \mathrm{N}, 10-30^{\circ} \mathrm{E}\right)$.

A polynya mask (red area in Fig. 1) is applied in order to cover an area comparable to previous studies (Skogseth et al., 2004, 2005; Jardon et al., 2014), as well as to limit the probability of remaining hidden cloud artifacts. The mask comprises a total area of $12594 \mathrm{~km}^{2}$ and has its southern limit at $77^{\circ} \mathrm{N}$ (following Skogseth et al., 2004), where a $120 \mathrm{~m}$ deep sill serves as kind of a boundary for the accumulation of brine-enriched shelf water in the Storfjorden basin (see Fig. 1).

\subsection{ERA-Interim reanalysis}

For the calculation of thin-ice thicknesses, atmospheric variables from the ERA-Interim reanalysis product (Dee et al., 2011) are used to provide $2 \mathrm{~m}$ temperature, $2 \mathrm{~m}$ dew point temperature, $10 \mathrm{~m}$ wind speed components ( $u$ and $v$ ) and the mean sea-level pressure at a temporal resolution of $6 \mathrm{~h}$. The data set is provided by the European Center for MediumRange Weather Forecasts (ECMWF) in a horizontal resolution of $0.75^{\circ}(\sim 79 \mathrm{~km})$. As the satellite data set is by far spatially higher resolved than the atmospheric data set, a linear interpolation of the ERA-Interim data is performed to match the MODIS data. In the course of the TIT calculations, each MODIS swath is linked to the closest time step of the atmospheric fields.

\subsection{Thin-ice thickness retrieval using a 1-D thermodynamic surface energy model}

In order to derive daily TIT distributions, we use an approach that follows the work of Yu and Rothrock (1996), Yu and Lindsay (2003) and Drucker et al. (2003), with most recent improvements and modifications made by Willmes et al. $(2010,2011)$ and Adams et al. (2013). The applied method utilizes the distinct relationship between IST and thickness of thin ice depending on atmospheric energy fluxes. The IST of very thin ice (with no snow cover) is close to the freezing point of the upper ocean layer and decreasing IST can be observed for thicker ice (Drucker et al., 2003; Kwok et al., 2007). However, IST is governed by atmospheric radiation fluxes and turbulent fluxes of heat, which does not allow for a simple relationship between IST and ice thickness. The ice thickness $h_{\text {ice }}$ (likewise abbreviated "TIT" for thin ice in the course of this paper) is therefore calculated using a 1-D thermodynamic sea-ice model.

Several assumptions have to be made to apply this model. First, the temperature profile through the ice is assumed to be linear. This approximation is valid for $h_{\text {ice }} \leq 0.5 \mathrm{~m}$ (Drucker et al., 2003). Second, the water temperature at the boundary between ice and ocean is constant and at its freezing point $\left(T_{\mathrm{f}}=271.35 \mathrm{~K}\right)$. Third, the ice is assumed to be free of snow. The ice thickness is calculated by using MODIS IST and ERA-Interim reanalysis data. The method is based on the condition, that the conductive heat flux through the ice ( $Q_{\text {ice }}$, Eq. 1) equals the total heat flux to the atmosphere $\left(Q_{\mathrm{atm}}\right.$, Eq. 2). This implies that all energy loss at the ice-surface is compensated by the conductive heat flux $Q_{\text {ice }}$.

$$
\begin{aligned}
& Q_{\text {ice }}=\kappa_{\text {ice }} \times \frac{\left(T_{\text {surf }}-T_{\mathrm{f}}\right)}{h_{\text {ice }}}, \\
& Q_{\text {atm }}=Q_{0}-H_{0}-E_{0},
\end{aligned}
$$

where $Q_{0}$ is the net radiation balance, $H_{0}$ and $E_{0}$ are the turbulent fluxes of sensible heat and latent heat, respectively, $\kappa_{\text {ice }}$ is the thermal conductivity of sea ice, $T_{\text {surf }}$ is the surface temperature, $T_{\mathrm{f}}$ is the freezing point of sea water and $h_{\text {ice }}$ is the ice thickness. Because of difficulties with the parametrization of shortwave radiation terms (Adams et al., 2013), only nighttime scenes were incorporated into the calculations (by checking the solar incidence angle on a pixelby-pixel basis), so that the radiation balance $Q_{0}$ simplifies to the long-wave radiation terms $L \downarrow$ and $L \uparrow$. Upwelling long-wave radiation $L \uparrow$ is calculated using the IST from MOD/MYD29 with the surface emissivity $\epsilon_{\mathrm{s}}$ set to $1 . L \downarrow$ can be obtained using ERA-Interim $2 \mathrm{~m}$ temperatures and the atmospheric emissivity $\epsilon_{\mathrm{atm}}$, calculated using the formulation of Jin et al. (2006). Turbulent fluxes of sensible $\left(H_{0}\right)$ and latent $\left(E_{0}\right)$ heat in Eq. (2) are calculated using an iterative bulk approach by Launiainen and Vihma (1990), where nearsurface stratification is considered using Monin-Obukhov similarity theory and associated universal functions for the 
heat transfer coefficients $C_{\mathrm{H}}$ and $C_{\mathrm{E}}$. The $10 \mathrm{~m}$ wind speed is interpolated to the $2 \mathrm{~m}$ level. A constant roughness length for momentum $z_{0}=1 \times 10^{-3} \mathrm{~m}$ is used. As could be shown by Adams et al. (2013), the standard approach used in previous studies using constant heat transfer coefficients tends to underestimate the ice thickness by approximately $7 \mathrm{~cm}$ on average, when compared to an iteratively calculated heat transfer coefficient. To obtain the ice thickness $\left(h_{\text {ice }}\right)$, the total atmospheric flux $Q_{\text {atm }}$ (Eq. 2) is set equal to the conductive heat flux through the ice ( $Q_{\text {ice }}$; Eq. 1), and Eq. (1) is solved for $h_{\text {ice }}$ using a value for the thermal conductivity of $\kappa_{\text {ice }}=2.03 \mathrm{Wm}^{-2} \mathrm{~K}^{-1}$ (Drucker et al., 2003).

Calculated ice thicknesses are assumed to be uniform at a given pixel location and therefore hypothetical (Tamura and Ohshima, 2011). The described method is only applicable to clear sky conditions, as clouds and fog strongly influence the accuracy of the recorded ISTs (Riggs et al., 2006).

In a sensitivity analysis of the above described method, Adams et al. (2013) state an uncertainty for the ice-thickness retrieval of $\pm 1.0, \pm 2.1$ and $\pm 5.3 \mathrm{~cm}$ for TIT classes $0-5,5-$ 10 and $10-20 \mathrm{~cm}$, respectively. Therefore, we constrain our analysis to ice thicknesses $\leq 0.2 \mathrm{~m}$, as this range is regarded sufficient to get reliable results for ice production ( $\mathrm{Yu}$ and Rothrock, 1996; Adams et al., 2013).

\subsubsection{Calculation of daily thin-ice thickness composites}

From all available MODIS swaths covering the Storfjorden polynya region, daily composites of ISTs and thin-ice thicknesses were computed. The TIT is first calculated from each swath on its own with the procedure described in Sect. 2.3. Subsequently, the mean TIT is computed pixel-wise and stored with its corresponding IST value.

By using daily composites, the daily IST coverage (percentage of pixels within the polynya mask that feature at least one valid IST value, based on all MOD/MYD29 swaths covering the Storfjorden region on a given day) is significantly increased compared to single swaths, reaching an average value of $82 \%$ for the winter seasons 2002/2003 to $2013 / 2014$. Figure 2 shows the seasonal and interannual variability of IST coverage. Noteworthy is a very low coverage in November to early January 2009/2010, as well as generally less frequent coverage at the beginning (November) and end (March) of each winter season. The latter effect originates from the previously stated restriction to nighttime scenes and consequently a reduction in the amount of available MODIS swaths. Hence, it is also the main reason why the months of October and April were left out in our investigations.

\subsubsection{Derivation of ice production and polynya area}

Following Tamura et al. (2007, 2008) and Willmes et al. (2011), daily ice production rates are calculated from the heat loss at the ice surface by assuming that the entire heat loss to the overlying atmosphere contributes to new ice formation.

$$
\frac{\partial h}{\partial t}=\frac{-\bar{Q}_{\text {ice }}}{\rho_{\text {ice }} \times L_{\mathrm{f}}}
$$

Therein, $\frac{\partial h}{\partial t}$ stands for the ice production rate, $\bar{Q}_{\text {ice }}$ is the daily mean conductive heat flux through the ice, $\rho_{\text {ice }}$ is the density of sea ice (taken as $\rho_{\text {ice }}=910 \mathrm{~kg} \mathrm{~m}^{-3}$ ) and $L_{\mathrm{f}}$ is the latent heat of fusion of ice $\left(L_{\mathrm{f}}=0.334 \mathrm{MJ} \mathrm{kg}^{-1}\right.$; e.g., Tamura and Ohshima, 2011). Note that the negative sign in the right side of Eq. (3) handles the convention that $Q_{\text {atm }}$ is considered positive when the surface gains energy, as well as considering that ice production only takes place when there is a net energy loss from the surface. Multiplying $\frac{\partial h}{\partial t}$ with the areal extent of each pixel in the regarded region yields the volume IP rate $\frac{\partial V}{\partial t}$. IP rates are calculated for each pixel with an ice thickness $\leq 0.2 \mathrm{~m}$ and afterwards extrapolated to daily rates for later accumulation and/or averaging. Considering the total polynya area, a threshold of $h_{\text {ice }} \leq 0.2 \mathrm{~m}$ is applied to identify pixels containing thin ice in the daily composites as part of the POLA. The total area of those pixels is then accumulated to obtain the total daily POLA in square kilometers.

\subsubsection{IST coverage correction}

Cloud-induced gaps in our daily IST and TIT composites are a serious problem when we want to compare our initially calculated POLA and IP to estimates from other studies in which the use of active and passive microwave remote sensing systems largely reduces the effect of atmospheric disturbances.

To overcome these difficulties, a simple scaling approach is applied that works under the assumption that pixels in the uncovered part of the masked (Fig. 1) daily composites also contribute to the total POLA by the same proportion as those areas that are covered by a IST signal.

The initially calculated daily POLA is therefore scaled by a factor $F$ :

$F=1 /$ coverage,

$\mathrm{POLA}_{\mathrm{CC}}=\mathrm{POLA} \times F$.

The coverage in Eq. (4) could range from 0 to 1, but we apply the correction only for coverages exceeding 0.5. Similarly, estimated IP values are also scaled by the same factor yielding a corrected ice production $\mathrm{IP}_{\mathrm{CC}}$.

Application of this correction scheme is limited to cases where the daily IST coverage (compare Fig. 2) within the fjord (i.e., the predefined polynya mask) surpasses a threshold of $50 \%$. By using this threshold, unrealistically high POLA $A_{C C}$ and $I_{C C}$ values are avoided. Otherwise, both POLA $A_{C C}$ and $I_{\mathrm{CC}}$ are linearly interpolated using bounding days with a coverage fulfilling this precondition.

In order to test the performance of the cloud-correction method, we selected a total of six case studies from Jan- 


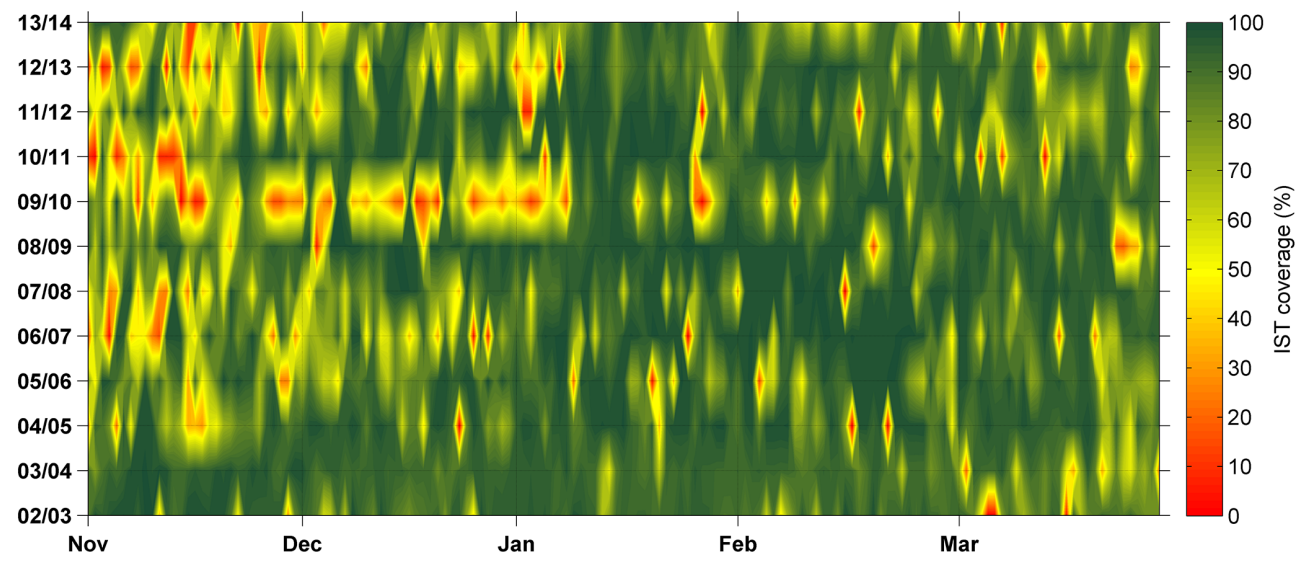

Figure 2. Interannual overview of the daily ice-surface temperature (IST) coverage (in \%) within the applied polynya mask (compare Fig. 1). Values are derived from daily MODIS IST composites for the complete investigation period from 2002/2003 to 2013/2014 (NovemberMarch).

uary 2009 (DOY 002, 020, 024, 025, 026, 030) which feature near-clear-sky conditions (IST coverage $\geq 99 \%$ ). The coverage correction has been applied for each case study after randomly removing $45 \%$ of the pixels within the polynya mask for 1000 realizations. The resulting deviation (in percent) from the "true" polynya area from all case studies combined is shown in Fig. 3. POLA ${ }_{\mathrm{CC}}$ deviations almost perfectly follow a typical normal (Gaussian) distribution, with a mean value of $0.77 \%$ and a standard error of $5-6 \%$ of the daily POLA.

Because the correction of IP values uses the same scaling factor $F$, the retrieved error margins can also be regarded as the uncertainty of our $\mathrm{IP}_{\mathrm{CC}}$ estimates.

\section{Results}

The bars in Fig. 4 show the mean relative contribution of each ice-thickness class from the total number of pixels with a TIT $\leq 0.2 \mathrm{~m}$ between the winter seasons $2002 / 2003$ and 2013/2014. A temporal differentiation between the beginning of the freezing season (November-December) and the end of the freezing season (January-March) as well as a combined distribution for the whole winter period is given. Error bars refer to \pm 1 standard deviation (SD) of the interannual averaged distribution frequencies. Between November and March, ice thinner than $0.02 \mathrm{~m}$ contributes around $15 \%$ to the total polynya area in an average winter season. Due to a higher sensitivity of open water and very thin ice for sea smoke effects and consequently an exclusion of thinice pixels by the cloud mask, this thickness class is potentially biased (Willmes et al., 2011). The average ice thickness within the polynya mask is $10 \pm 1.8 \mathrm{~cm}$. Thicker ice classes $(>0.1 \mathrm{~m})$ cover around half of the entire Storfjorden polynya in January to March and show overall lower contributions at the beginning of the freezing season. This follows from the

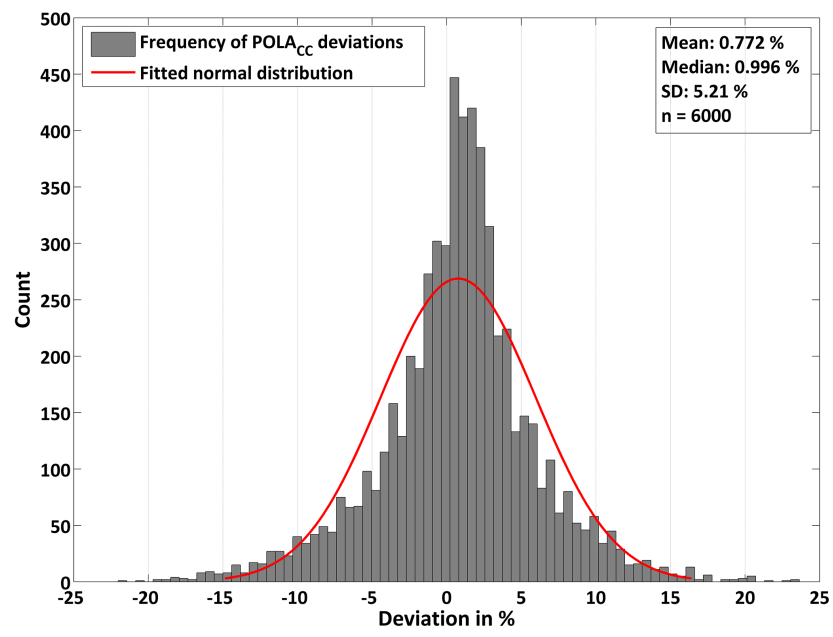

Figure 3. Histogram of coverage-corrected polynya area (POLA $_{C C}$ ) deviations, based on six near-clear-sky case studies from January 2009 (DOY: 002, 020, 024, 025, 026, 030). For each case study, the coverage correction was repeated several times $(n=1000 \times 6)$, after randomly removing $45 \%$ of the pixels within the applied polynya mask.The red curve illustrates a fitted normal distribution.

high contribution of very thin ice in November to December, where over $60 \%$ of the total POLA consists of ice thinner than $0.1 \mathrm{~m}$. SD is highest in the lowest thickness classes $(<0.04 \mathrm{~m})$ and appears to be lower towards the end of the freezing season, possibly indicating a stronger seasonal variability of ice-thickness distributions within the polynya in November and December over the 12-year record (also apparent in relative TIT frequencies for November-December; Fig. 5).

Spatial distributions of the relative TIT frequency for $2002 / 2003$ to $2013 / 2014$ are presented as a seasonal comparison between the beginning of each freezing season 

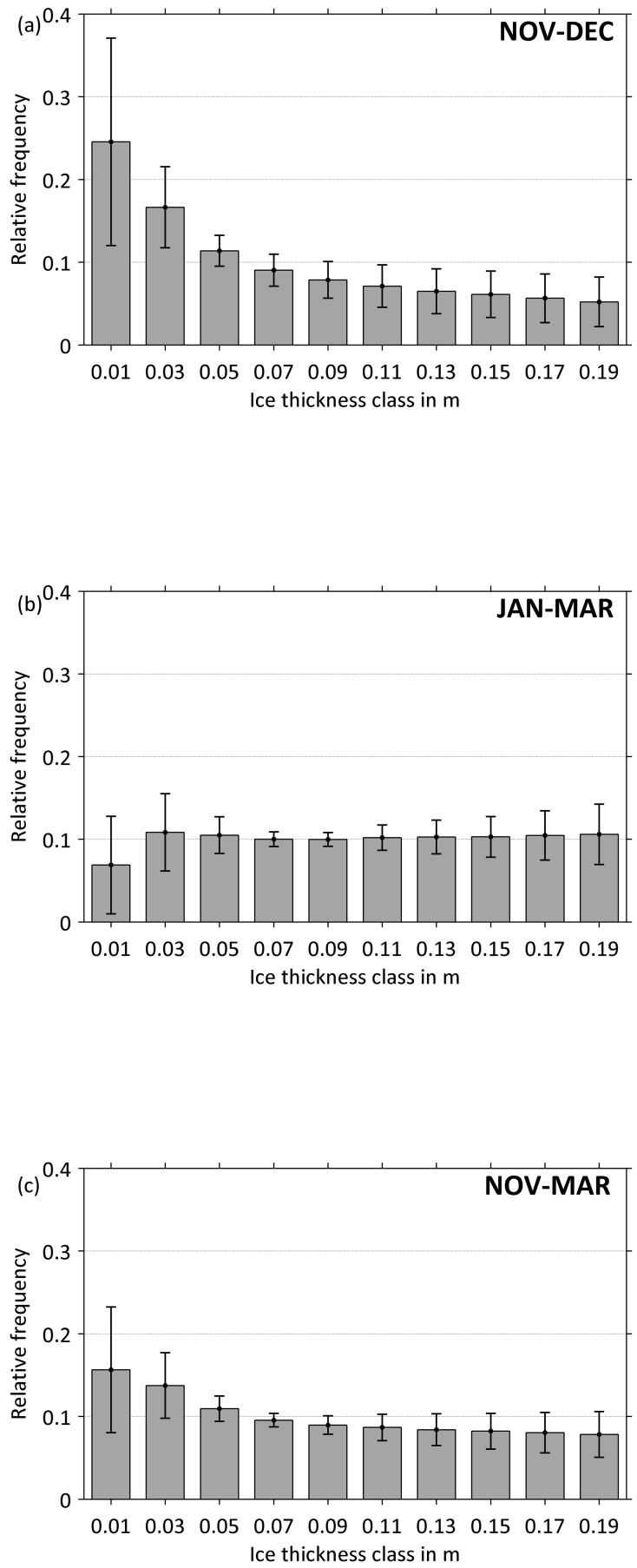

Figure 4. Relative thin-ice thickness (TIT) distribution in the Storfjorden polynya, with ice-thickness classes of $2 \mathrm{~cm}$ range ( $x$ axis). Input data are based on daily TIT composites. The bars indicate the mean relative distribution of each thickness class from the total number of TIT $\leq 0.2 \mathrm{~m}$ appearances between the winter seasons $2002 / 2003$ and 2013/2014. Error bars refer to \pm 1 SD. Besides an overview of the complete freezing season from November to March (c), it is further separated between the months November and December (a) as well as January to March (b).
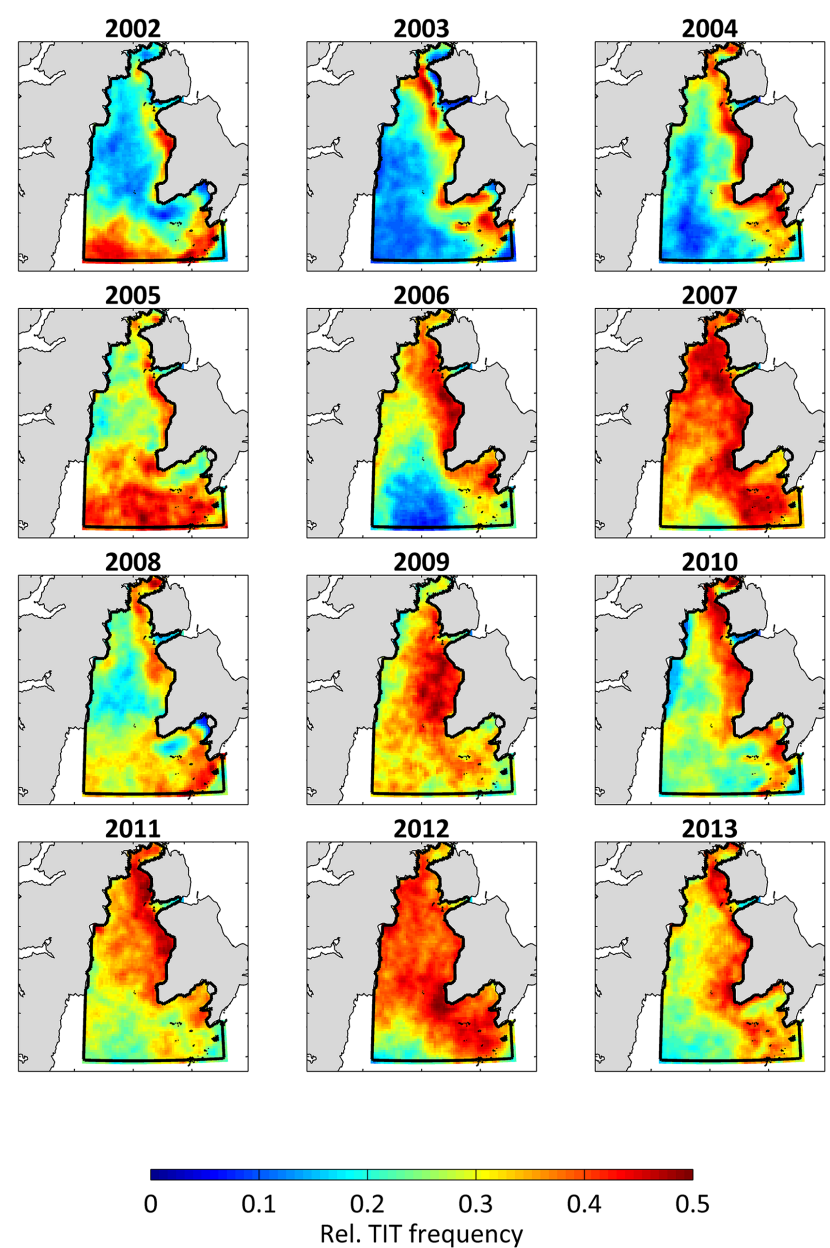

Figure 5. Early freezing season (November to December) relative frequency distribution of thin-ice thicknesses $\leq 0.2 \mathrm{~m}$ for 2002 to 2013, based on daily TIT composites.

(November-December, Fig. 5) and the end of each freezing season (January-March, Fig. 6). Therein, a pixel value of, e.g., 0.25 means that on $25 \%$ of all days, a TIT threshold of $0.2 \mathrm{~m}$ was not exceeded. Following the previously stated definition of a polynya, these pixels represent the number of polynya occurrences in the given period. Figure 6 shows that the main regions for polynya development towards the end of the freezing season are at the lee sides of Barentsøya and Edgeøya at the eastern side of the fjord, extending more (2006-2008, 2010, 2012-2014) or less (2003-2005, 2009, 2011) further southwestwards.

At the beginning of the freezing season (Fig. 5), annual distributions show a more variable pattern of TIT frequencies. In some years (e.g., 2007, 2009, 2012), frequencies exceeding 0.3 cover large areas within the masked area in Storfjorden, which might be an effect of a late fall freeze-up and subsequently longer periods with thin ice and open water in the fjord. In other years (e.g., 2003, 2004), the observed pattern of high TIT frequencies is similar to typical polynya 

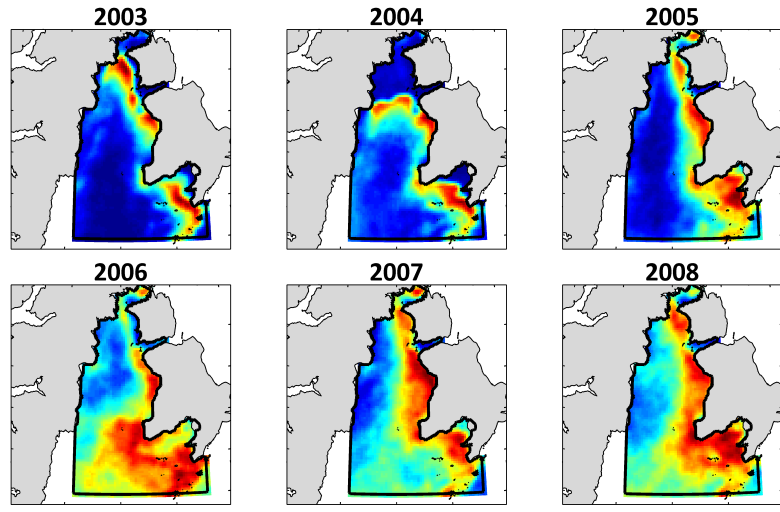

2009

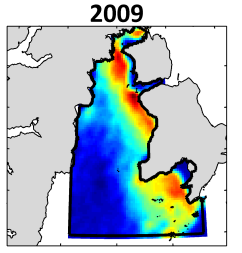

2012
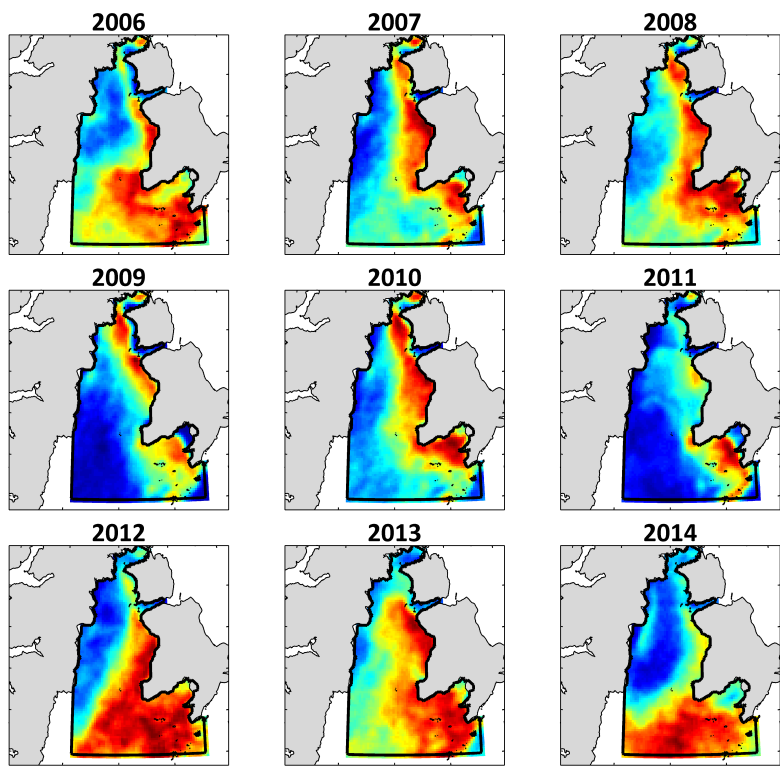

2010
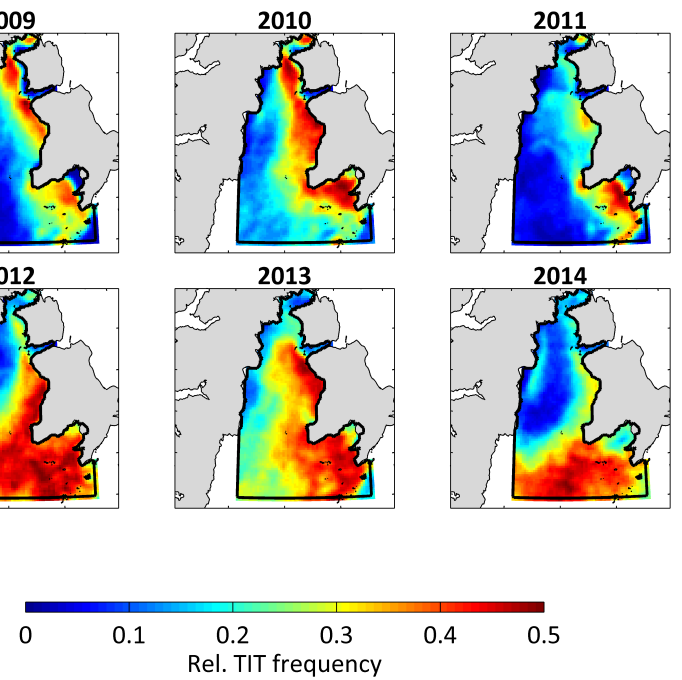

Figure 6. Late freezing season (January to March) relative frequency distribution of thin-ice thicknesses $\leq 0.2 \mathrm{~m}$ for 2003 to 2014, based on daily TIT composites.

locations between January and March, indicating an earlier freeze-up of the ice cover in Storfjorden.

Frequent TIT occurrences in the southern part of Storfjorden could originate from a generally northwards retreating ice edge in Storfjorden in some of the regarded winter seasons. This becomes most obvious in 2006, 2008 and 2012 to 2014 (Fig. 6). Low values $(<0.05)$ at the (north) western side of Storfjorden towards the end of a freezing season (Fig. 6) further indicate typical fast-ice areas, which are most pronounced in the years 2003, 2004, 2005, 2007, 2009 and 2011.

The daily coverage-corrected (CC) polynya area (POLA $A_{C C}$ ) for all winters (November-March) between $2002 / 2003$ and 2013/2014 is presented in Fig. 7. Highest POLA $_{C C}$ values are generally found in November and December, which might be an effect of the already mentioned late fall freeze-up and therefore very thin newly formed ice (compare Figs. 4a and 5) in large parts of Storfjorden. From 2006 to 2008 and 2012 to 2013, this effect even extends
Table 2. Accumulated ice production (IP) in cubic kilometers per winter and average polynya area (POLA) in square kilometers for each winter season (November to March) in the Storfjorden polynya, together with the interannual average (mean) and its standard deviation (SD). CC denotes values after coverage correction, with relative increase compared to uncorrected values in brackets. All values are calculated within the predefined polynya mask (Fig. 1).

\begin{tabular}{lrrrr}
\hline & $\begin{array}{r}\text { Acc. IP } \\
\left(\mathrm{km}^{3}\right)\end{array}$ & $\begin{array}{r}\text { Acc. IP } \\
\left(\mathrm{km}^{3}\right)\end{array}$ & $\begin{array}{r}\text { POLA } \\
\left(\mathrm{km}^{2}\right)\end{array}$ & $\begin{array}{r}\text { POLACC } \\
\left(\mathrm{km}^{2}\right)\end{array}$ \\
\hline $2002-2003$ & 13.9 & $16.1(+16 \%)$ & 2185.2 & $2429.6(+11 \%)$ \\
$2003-2004$ & 15.2 & $16.7(+10 \%)$ & 2186.6 & $2382.0(+9 \%)$ \\
$2004-2005$ & 19.2 & $23.7(+24 \%)$ & 2684.7 & $3296.6(+23 \%)$ \\
$2005-2006$ & 20.6 & $25.1(+22 \%)$ & 3934.8 & $4750.6(+21 \%)$ \\
$2006-2007$ & 19.4 & $25.3(+31 \%)$ & 3473.9 & $4524.2(+30 \%)$ \\
$2007-2008$ & 27.4 & $33.1(+21 \%)$ & 4491.0 & $5472.5(+22 \%)$ \\
$2008-2009$ & 21.6 & $24.6(+14 \%)$ & 2965.4 & $3353.3(+13 \%)$ \\
$2009-2010$ & 17.3 & $30.0(+73 \%)$ & 3390.1 & $6357.0(+88 \%)$ \\
$2010-2011$ & 23.2 & $31.9(+38 \%)$ & 2996.0 & $4024.7(+34 \%)$ \\
$2011-2012$ & 21.5 & $29.6(+38 \%)$ & 4087.6 & $5001.5(+22 \%)$ \\
$2012-2013$ & 36.0 & $47.2(+31 \%)$ & 5592.4 & $7388.0(+32 \%)$ \\
$2013-2014$ & 25.4 & $36.5(+44 \%)$ & 4154.3 & $5688.4(+37 \%)$ \\
\hline Mean & 21.7 & $28.3(+30 \%)$ & 3511.8 & $4555.7(+29 \%)$ \\
SD & 5.9 & 8.5 & 999.6 & 1542.9 \\
\hline
\end{tabular}

well into January with a series of large POLA $\mathrm{CC}_{\mathrm{C}}$ events $\left(>5000 \mathrm{~km}^{2}\right)$ developing in February and March.

The mean (November to March) POLA for the entire regarded period amounts to $3511.8 \pm 999.6 \mathrm{~km}^{2}$, with an increase of $29 \%$ for POLA $\mathrm{CC}_{\mathrm{CC}}$ when the presented coverage correction is applied. Around $60 \%$ of this area consists of ice thinner than $10 \mathrm{~cm}$. A complete overview on wintertime mean POLA and POLA ${ }_{C C}$ values is given in Table 2.

A spatial overview of the resulting accumulated daily ice production rates (in $\mathrm{mwinter}^{-1}$ ), averaged between 2002/2003 and 2013/2014 is presented in Fig. 8. Largest values occur in regions which also show high TIT frequencies (Fig. 6). The average ice production in the western part of Storfjorden is generally lower, as thin ice in these areas is mainly present at the beginning of the freezing season.

Maximum daily ice production rates in the fjord can reach as high as $26 \mathrm{cmd}^{-1}$ (winter season 2006/2007), with the highest rates occurring on average in the northern part of Storfjorden (north of $77.5^{\circ} \mathrm{N}$ ).

Figure 9 shows values of accumulated ice production per winter season from November to March, both with and without applied coverage correction. The impact of seasonal differences is highlighted in yellowish and blueish colored bars. A detailed overview for each winter season is additionally given in Table 2 . On average, the correction scheme increases the wintertime ice production by approximately $30 \%$. While the average IP value is $28.3 \pm 8.5 \mathrm{~km}^{3}$ (CC; $21.7 \pm 5.9 \mathrm{~km}^{3}$ for no $\mathrm{CC}$ ), a high interannual variability of ice production is found, with values as low as $16.1 \mathrm{~km}^{3}$ (CC; no $\mathrm{CC}-16 \%$ ) in $2002 / 2003$ and up to $47.2 \mathrm{~km}^{3}$ (CC; no 


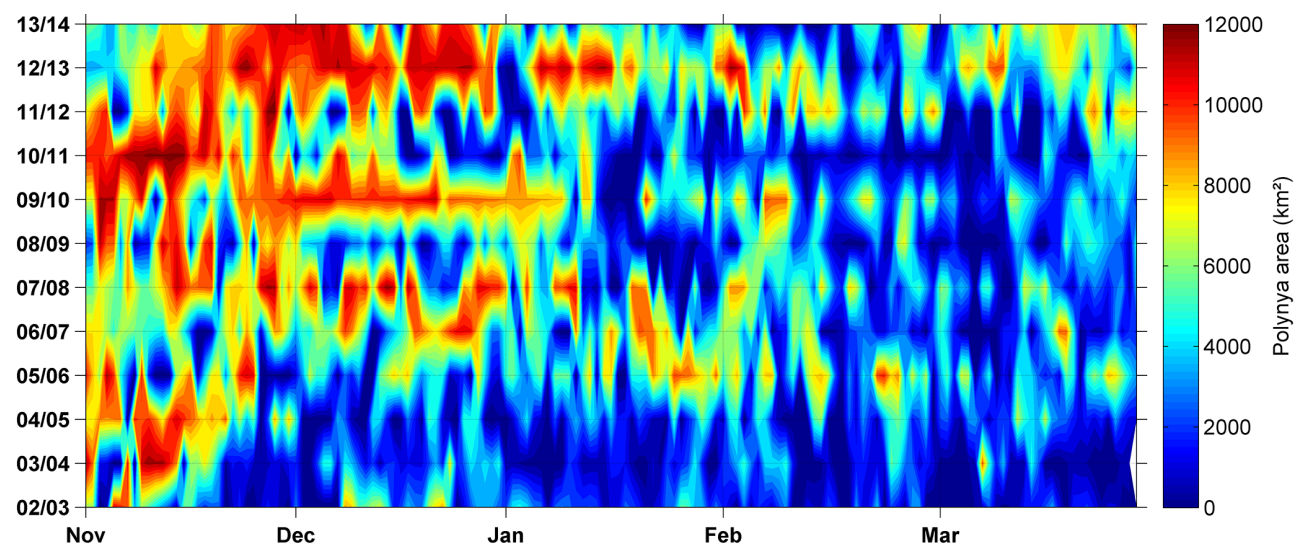

Figure 7. Hovmöller diagram of daily coverage-corrected polynya area (POLA $\mathrm{CC}_{\mathrm{C}}$ TIT $\left.\leq 0.2 \mathrm{~m}\right)$ in the Storfjorden polynya between $2002 / 2003$ and 2013/2014.

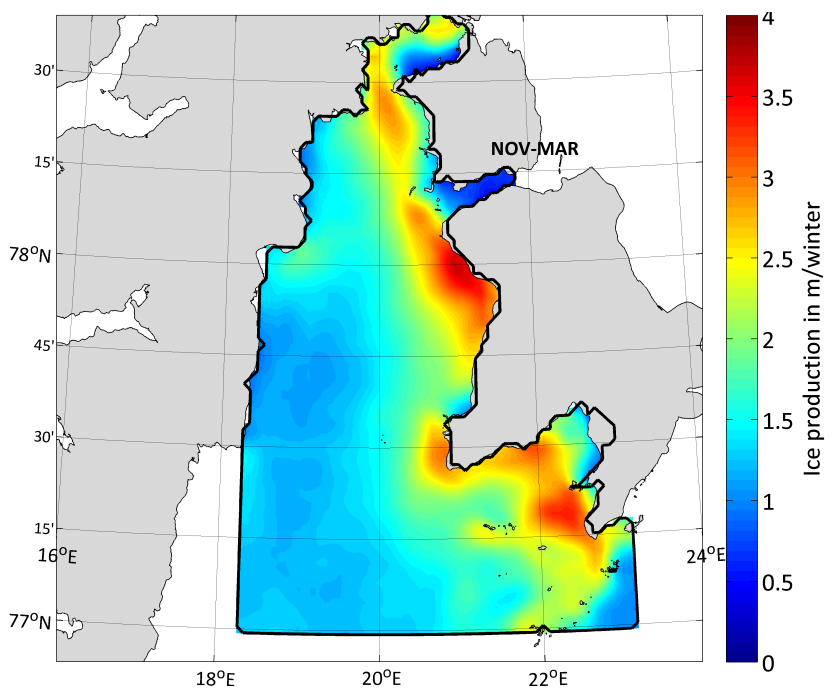

Figure 8. Spatial distribution of the interannual mean accumulated ice production (IP) rate in winter $^{-1}$. Values are first accumulated for each winter season from November to March and afterwards averaged for $2002 / 2003$ to $2013 / 2014$.

CC $-31 \%$ ) in 2012/2013. Large increases in IP occur from winter 2003/2004 to 2004/2005 (CC: $\left.+7.0 \mathrm{~km}^{3}\right)$ and again from winter 2011/2012 to 2012/2013 (CC: $\left.+17.6 \mathrm{~km}^{3}\right)$. This could originate from the increasing extent of thin-ice areas in January-March 2005 and 2013 compared to the same period in 2004 and 2012 (Fig. 6). Regardless of an applied coverage correction, a significant $(p \leq 0.05)$ positive trend of $1.2-2.0 \mathrm{~km}^{3} \mathrm{yr}^{-1}$ over the examined 12-winter period can be observed. It shows that this trend in overall (NovemberMarch) $\mathrm{IP}_{\mathrm{CC}}$ originates primarily from a significant positive trend $\left(\mathrm{CC}: 1.29 \mathrm{~km}^{3} \mathrm{yr}^{-1}, p=9.05 * 10^{-4}\right.$ ) at the beginning of winter (November-December), while the period from January to March shows no significant trend (CC: $0.73 \mathrm{~km}^{3} \mathrm{yr}^{-1}$, $p=0.052$ ). This could be an effect of an observable shift

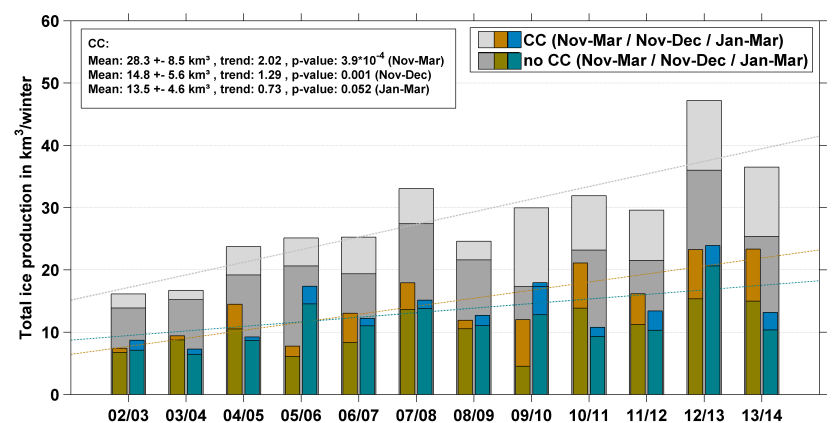

Figure 9. Annual wintertime accumulated ice production in the Storfjorden polynya, given in cubic kilometers per winter. Estimations are based on daily heat flux calculations using the daily derived thin-ice thickness (TIT) composites. Special emphasis is given to the effect of an applied coverage correction (CC). Dotted lines show linear trend estimations for $\mathrm{IP}_{\mathrm{CC}}$. Colored bars show a seasonal comparison between November and December (yellowish) and January and March (blueish).

towards more thin ice in November-December, which is most probably connected to the later appearing fall freezeup and consequently a lot of open water and very thin ice in the southern part of the applied polynya-mask. A similar explanation can be given for the high ice production in 2012/2013, where the Storfjorden area features high frequencies of TIT $\leq 0.2 \mathrm{~m}$ throughout the whole winter season from November to March.

\section{Discussion}

In Skogseth et al. (2004, 2005), a manual classification of several ERS-2 synthetic aperture radar (SAR) images from 1998 to 2002 was performed to derive parameters for a winddriven polynya width model (Haarpaintner et al., 2001), which gives estimates of ice production and brine-enriched shelf water based on satellite imagery, wind data from nearby 
weather stations and surface hydrography. Ice production was calculated from surface heat balance and includes contributions from open water (frazil ice), thin ice as well as fast and pack ice inside the Storfjorden basin north of $77^{\circ} \mathrm{N}$. This setup was later extended to a 33-year record of modeled total ice production covering the winters 1970 to 2002 using model parameters derived from the examined 5-winter period (Skogseth et al., 2005). While the average total ice production for 1998 to 2002 was estimated to $43.6 \pm 9.7 \mathrm{~km}^{3}$, it was slightly lower for the 33-year time series with only $39.9 \pm 11.7 \mathrm{~km}^{3}$. When comparing these numbers to our average $\mathrm{IP}_{\mathrm{CC}}$ estimate of $28.3 \pm 8.5 \mathrm{~km}^{3}$ for $2002 / 2003$ to 2013/2014, one has to keep in mind that Skogseth et al. $(2004,2005)$ also include ice production under fast and pack ice inside the fjord, while our study concentrates on open water and thin-ice areas only. Assuming an average contribution of $25 \%$ from fast-ice and pack-ice areas (Table 3 in Skogseth et al., 2005) and after reducing annually accumulated total ice production accordingly, the average ice production (1970 to 2002) inside open water and thin-ice areas of Skogseth et al. (2005) is lowered to approximately $30 \pm 9 \mathrm{~km}^{3}$ which is within the standard deviation presented here. Skogseth et al. (2005) give some further information on the interannual variability of ice production within the Storfjorden polynya, although it is stated that the uncertainty for the 33year time series is increased. The presented 33-year time series shows a slightly negative and non-significant trend of approximately $-2 \mathrm{~km}^{3} \mathrm{decade}^{-1}$, while the last 12 winter seasons presented here show a positive trend of $2.02 \mathrm{~km}^{3} \mathrm{yr}^{-1}$ during the analyzed period. However, the long-term model estimates by Skogseth et al. (2005) indicate the presence of multi-decadal fluctuations.

Jardon et al. (2014) developed an ice production model which uses Advanced Microwave Scanning Radiometer Earth Observing System (AMSR-E) sea-ice concentration data to derive daily open water fractions. Heat flux calculations over water were performed using ERA-Interim reanalysis data in a bulk algorithm. In contrast to our results, their estimates of POLA and IP incorporate both frazil ice growth as well as ice growth under ice thicker than $20 \mathrm{~cm}$. In comparison, our results should profit from the enhanced resolution of MODIS and daily derived TIT distributions. Nevertheless, derived POLA from TIT $\leq 0.2 \mathrm{~m}$ in our study compares well with POLA derived from AMSR-E sea-ice concentration data. Both wintertime mean POLA and POLA $\mathrm{CC}_{\mathrm{C}}$ are within the 25th and 75th percentile of the estimated open water area by Jardon et al. (2014) in almost every winter season except for 2004/2005 and 2010/2011, during which both values derived by MODIS exceed the 75th percentile. Discrepancies in derived total ice production are obvious but can be partly explained by differences in the regarded time frame of each winter season. While Jardon et al. (2014) analyze the full period with sea ice in the fjord (roughly October/November to June/July), we focus on the November to March period. Even when we reduce the presented IP val- ues by the amount of frazil ice that is formed in the months April-July, which in 2006/2007 (example shown in Jardon et al., 2014) contributed around $15 \%$ to the total volume of frazil ice in this particular winter season, the time series differ on average by approx. $40 \%$. Therefore, Jardon et al. (2014) presents higher IP values in all winter seasons except $2004 / 2005$ and $2010 / 2011$, but overall the interannual variability is comparable.

The studies by Tamura and Ohshima (2011) and Iwamoto et al. (2014) face similar restrictions concerning the spatial resolution of the applied passive microwave data from Special Sensor Microwave Imager (SSM/I) and AMSR-E, which is most apparent in smaller polynyas such as in Storfjorden. In Tamura and Ohshima (2011), an average ice production of $137 \pm 35 \mathrm{~km}^{3}$ for the period 1992-2007 (September-May) is presented. This value largely exceeds our estimates as well as those by Skogseth et al. (2005) and Jardon et al. (2014), most probably due to the discrepancies in spatial resolution of the input data. More recent numbers by Iwamoto et al. (2014), who use an updated algorithm based on MODIS and AMSRE satellite data as well as ERA-Interim reanalysis, are also lower than those in Tamura and Ohshima (2011), with the mean annual (also September-May) ice production between 2002/2003 and 2010/2011 estimated as $47 \pm 5 \mathrm{~km}^{3}$ (roughly $40 \mathrm{~km}^{3}$ for November-March; based on presented monthly mean values). A positive trend of $3 \mathrm{~km}^{3}$ per decade is presented which is much smaller than our value of $18.7 \mathrm{~km}^{3}$ per decade based on the same period from 2002/2003 to 2010/2011. Although Iwamoto et al. (2014) provide enhancements in terms of spatial resolution and the inclusion of land fast-ice detection in comparison to Tamura and Ohshima (2011), our estimates are still exceeded in every winter season. The presented interannual variability is similar to our study, with 2005/2006 and 2008/2009 being the only winter seasons with a strongly contrasting development. Both Tamura and Ohshima (2011) and Iwamoto et al. (2014) apply noticeably larger polynya masks to derive ice production values in the Storfjorden area which extend well into the Greenland and Barents Sea regions and far beyond Storfjorden itself. This omission of local characteristics in the Storfjorden basin in addition to a differing base period, which spans the months from September to May, could therefore explain part of the difference. However, the use of coarse-resolution passive microwave data certainly leads to a higher uncertainty of IP estimates, while the sign of the bias cannot be determined here. It will depend on the distribution of thin ice within the sensor's footprint and potential land spillover effects.

\section{Summary and conclusions}

In this study, we presented a comprehensive overview of daily thin-ice thickness distributions and resulting thermodynamic ice production rates for the Storfjorden polynya, located in the southern part of the Svalbard archipelago. The 
investigation period covers the winter seasons 2002/20032013/2014 from November to March. Our results are complementary to previous studies in the Storfjorden region (e.g., Skogseth et al., 2004, 2005; Hendricks et al., 2011) and underline the importance of this polynya considering the total amount of ice production and accompanied salt release each winter season, despite its comparatively small spatial extent. Within the polynya, ice thicknesses below $10 \mathrm{~cm}$ dominate in the course of an average winter season and cover larger areas in the eastern part of Storfjorden. This enables ice production rates, which sum up to an average value of $28.3 \pm 8.5 \mathrm{~km}^{3}$ per winter season. There is a positive trend in accumulated ice production over the last 12 winter seasons which contrasts earlier indications of a slightly negative trend prior to 2002 (Skogseth et al., 2005).

Compared to other studies which rely on active and passive microwave remote sensing, the use of MODIS ice-surface temperatures has distinct drawbacks considering the effect of clouds, which produce data gaps when correctly identified by the MODIS cloud mask and possibly erroneous IST values when nighttime clouds remain undetected. By composing daily composites, data gaps in the Storfjorden region were minimized, resulting in an average IST coverage of $82 \%$ within the applied polynya mask. The application of a coverage-correction scheme yielded plausible adjustments of approximately $30 \%$ to the total polynya area and ice production, although its current basic approach offers room for future improvements such as including long-term spatial statistics. Still, this comprehensive data set will be of high value for a variety of climate and ocean applications, including the provision of quasi-daily high-resolution thin-ice thickness charts for regional climate and ocean models.

Acknowledgements. The authors want to thank the National Snow and Ice Data Center (NSIDC) as well as the European Center for Medium-Range Weather Forecasts (ECMWF) for providing the MODIS sea-ice product and the ERA-Interim atmospheric reanalysis data. This work was part of the German-Russian cooperation "WTZ RUS: System Laptev Sea: TRANSDRIFT" funded by the Federal Ministry of Education and Research (BMBF) under grant 03 G0833D. We would like to thank the three anonymous referees and Christian Haas for their very detailed and helpful reviews.

Edited by: C. Haas

\section{References}

Adams, S., Willmes, S., Schroeder, D., Heinemann, G., Bauer, M., and Krumpen, T.: Improvement and sensitivity analysis of thermal thin-ice retrievals, IEEE T. Geosci. Remote, 51, 3306-3318, doi:10.1109/tgrs.2012.2219539, 2013.

Barber, D. G. and Massom, R. A.: The Role of Sea Ice in Arctic and Antarctic Polynyas, in: Polynyas - Windows to the World, in: The Role of Sea Ice in Arctic and Antarctic Polynyas, edited by:
Smith, W. O. and Barber, D. G., 1-54, Elsevier Oceanography Series, doi:10.1016/s0422-9894(06)74001-6, 2007.

Bauer, M., Schröder, D., Heinemann, G., Willmes, S., and Ebner, L.: Quantifying polynya ice production in the Laptev Sea with the COSMO model, Polar Res., 32, 20922, doi:10.3402/polar.v32i0.20922, 2013.

Dee, D. P., Uppala, S. M., Simmons, A. J., Berrisford, P., Poli, P., Kobayashi, S., Andrae, U., Balmaseda, M. A., Balsamo, G., Bauer, P., Bechtold, P., Beljaars, A. C. M., van de Berg, L., Bidlot, J., Bormann, N., Delsol, C., Dragani, R., Fuentes, M., Geer, A. J., Haimberger, L., Healy, S. B., Hersbach, H., Hólm, E. V., Isaksen, L., Kållberg, P., Köhler, M., Matricardi, M., McNally, A. P., Monge-Sanz, B. M., Morcrette, J.-J., Park, B.-K., Peubey, C., de Rosnay, P., Tavolato, C., Thépaut, J.-N., and Vitart, F.: The ERA-Interim reanalysis: configuration and performance of the data assimilation system, Q. J. Roy. Meteor. Soc., 137, 553-597, doi:10.1002/qj.828, 2011.

Drucker, R., Martin, S., and Moritz, R.: Observations of ice thickness and frazil ice in the St. Lawrence Island polynya from satellite imagery, upward looking sonar, and salinity/temperature moorings, J. Geophys. Res., 108, 3149, doi:10.1029/2001jc001213, 2003.

Ebner, L., Schröder, D., and Heinemann, G.: Impact of Laptev Sea flaw polynyas on the atmospheric boundary layer and ice production using idealized mesoscale simulations, Polar Res., 30, 7210, doi:10.3402/polar.v30i0.7210, 2011.

Haarpaintner, J., Gascard, J.-C., and Haugan, P. M.: Ice production and brine formation in Storfjorden, Svalbard, J. Geophys. Res.Oceans, 106, 14001-14013, doi:10.1029/1999jc000133, 2001.

Hall, D., Key, J., Casey, K., Riggs, G., and Cavalieri, D.: Sea ice surface temperature product from MODIS, IEEE T. Geosci. Remote, 42, 1076-1087, doi:10.1109/tgrs.2004.825587, 2004.

Hendricks, S., Gerland, S., Smedsrud, L., Haas, C., Pfaffhuber, A., and Nilsen, F.: Sea-ice thickness variability in Storfjorden, Svalbard, Ann. Glaciol., 52, 61-68, doi:10.3189/172756411795931561, 2011.

Iwamoto, K., Ohshima, K. I., and Tamura, T.: Improved mapping of sea ice production in the Arctic Ocean using AMSR-E thin ice thickness algorithm, J. Geophys. Res.-Oceans, 119, 3574-3594, doi:10.1002/2013jc009749, 2014.

Jakobsson, M., Mayer, L., Coakley, B., Dowdeswell, J. A., Forbes, S., Fridman, B., Hodnesdal, H., Noormets, R., Pedersen, R., Rebesco, M., Schenke, H. W., Zarayskaya, Y., Accettella, D., Armstrong, A., Anderson, R. M., Bienhoff, P., Camerlenghi, A., Church, I., Edwards, M., Gardner, J. V., Hall, J. K., Hell, B., Hestvik, O., Kristoffersen, Y., Marcussen, C., Mohammad, R., Mosher, D., Nghiem, S. V., Pedrosa, M. T., Travaglini, P. G., and Weatherall, P.: The international bathymetric chart of the Arctic Ocean (IBCAO) version 3.0, Geophys. Res. Lett., 39, 12, doi:10.1029/2012g1052219, 2012.

Jardon, F., Vivier, F., Bouruet-Aubertot, P., Lourenço, A., Cuypers, Y., and Willmes, S.: Ice production in Storfjorden (Svalbard) estimated from a model based on AMSR-E observations: Impact on water mass properties, J. Geophys. Res.-Oceans, 119, 377-393, doi:10.1002/2013jc009322, 2014.

Jin, X., Barber, D., and Papakyriakou, T.: A new clear-sky downward longwave radiative flux parameterization for Arctic areas based on rawinsonde data, J. Geophys. Res., 111, D24104, doi:10.1029/2005jd007039, 2006. 
Krumpen, T., Hölemann, J. A., Willmes, S., Maqueda, M., Busche, T., Dmitrenko, I. A., Gerdes, R., Haas, C., Heinemann, G., Hendricks, S., Kassens, H., Rabenstein, L., and Schröder, D.: Sea ice production and water mass modification in the eastern Laptev Sea, J. Geophys. Res.-Oceans, 116, C05014, doi:10.1029/2010JC006545, 2011.

Kwok, R., Comiso, J. C., Martin, S., and Drucker, R.: Ross Sea polynyas: Response of ice concentration retrievals to large areas of thin ice, J. Geophys. Res., 112, C12012, doi:10.1029/2006jc003967, 2007.

Launiainen, J. and Vihma, T.: Derivation of turbulent surface fluxes - An iterative flux-profile method allowing arbitrary observing heights, Environ. Softw., 5, 113-124, doi:10.1016/02669838(90)90021-w, 1990.

Morales-Maqueda, M., Willmott, A., and Biggs, N.: Polynya dynamics: A review of observations and modeling, Rev. Geophys., 42, 1-37, doi:10.1029/2002rg000116, 2004.

Riggs, G., Hall, D., and Salomonson, V.: MODIS Sea Ice Products User Guide to Collection 5, National Snow and Ice Data Center, University of Colorado, Boulder, CO 80309-0449 USA, available at: http://nsidc.org/data/docs/daac/modis_v5/dorothy_ ice_doc.pdf (last access: 11 May 2015), 2006.

Skogseth, R., Haugan, P., and Haarpaintner, J.: Ice and brine production in Storfjorden from four winters of satellite and in situ observations and modeling, J. Geophys. Res.-Oceans, 109, C10008, doi:10.1029/2004jc002384, 2004.

Skogseth, R., Fer, I., and Haugan, P. M.: Dense-Water Production and Overflow from an Arctic Coastal Polynya in Storfjorden, The Nordic Seas: An Integrated Perspective, 73-88, doi:10.1029/158gm07, 2005.

Skogseth, R., McPhee, M. G., Nilsen, F., and Smedsrud, L. H.: Creation and tidal advection of a cold salinity front in Storfjorden: 1. Polynya dynamics, J. Geophys. Res.-Oceans, 118, 3278-3291, doi:10.1002/jgrc.20231, 2013.
Smith, S. D., Muench, R. D., and Pease, C. H.: Polynyas and leads: An overview of physical processes and environment, J. Geophys. Res., 95, 9461-9479, doi:10.1029/jc095ic06p09461, 1990.

Tamura, T. and Ohshima, K. I.: Mapping of sea ice production in the Arctic coastal polynyas, J. Geophys. Res., 116, C07030, doi:10.1029/2010jc006586, 2011.

Tamura, T., Ohshima, K. I., Markus, T., Cavalieri, D. J., Nihashi, S., and Hirasawa, N.: Estimation of Thin Ice Thickness and Detection of Fast Ice from SSM/I Data in the Antarctic Ocean, J. Atmos. Ocean. Tech., 24, 1757-1772, doi:10.1175/jtech2113.1, 2007.

Tamura, T., Ohshima, K. I., and Nihashi, S.: Mapping of sea ice production for Antarctic coastal polynyas, Geophys. Res. Lett., 35, L07606, doi:10.1029/2007g1032903, 2008.

Willmes, S., Krumpen, T., Adams, S., Rabenstein, L., Haas, C., Hoelemann, J., Hendricks, S., and Heinemann, G.: Crossvalidation of polynya monitoring methods from multisensor satellite and airborne data: a case study for the Laptev Sea, Can. J. Remote Sens., 36, S196-S210, doi:10.5589/m10-012, 2010.

Willmes, S., Adams, S., Schröder, D., and Heinemann, G.: Spatiotemporal variability of polynya dynamics and ice production in the Laptev Sea between the winters of 1979/80 and 2007/08, Polar Res., 30, 5971, doi:10.3402/polar.v30i0.5971, 2011.

Yu, Y. and Lindsay, R.: Comparison of thin ice thickness distributions derived from RADARSAT Geophysical Processor System and advanced very high resolution radiometer data sets, J. Geophys. Res., 108, 3387, doi:10.1029/2002jc001319, 2003.

Yu, Y. and Rothrock, D. A.: Thin ice thickness from satellite thermal imagery, J. Geophys. Res., 101, 25753-25766, doi:10.1029/96jc02242, 1996. 